\title{
HUBUNGAN ANTARA PENDIDIKAN ORANG TUA DENGAN STATUS GIZI ANAK PADA KELUARGA BINAAN FK UMSU
}

\author{
Filia Amanda Lubis ${ }^{1}$, Elman Boy ${ }^{2}$ \\ ${ }^{1}$ Fakultas Kedokteran Universitas Muhammadiyah Sumatera Utara \\ ${ }^{2}$ Bagian Ilmu Kesehatan Masyarakat Universitas Muhammadiyah Sumatera Utara
}

\begin{abstract}
ABSTRAK
Latar belakang: Masalah gizi tidak lagi hanya masalah kesehatan, tetapi juga masalah pendidikan, kemiskinan, dan kesempatan kerja. Ada 4 sub-bentuk defisiensi nutrisi: wasting, stunting, underweight, dan defisiensi vitamin dan mineral. Banyak penelitian telah membuktikan bahwa salah satu penyebab dasar wasting dan stunting adalah kondisi rendahnya pendidikan dan ekonomi keluarga. Penelitian ini bertujuan untuk mengetahui hubungan tingkat pendidikan orang tua dengan status gizi anak usia sekolah dasar pada keluarga binaan FK UMSU. Metode: Penelitian ini adalah penelitian deskriptif analitik dengan desain crosssectional. Populasi penelitian ini berjumlah 25 ibu dengan 43 total anak yang terdaftar sebagai anggota Keluarga Asuh Fakultas Kedokteran Universitas Muhammadiyah Sumatera Utara. Teknik pengambilan sampel menggunakan metode total sampling. Hasil: Tidak ada hubungan antara pendidikan orang tua dan status gizi anak-anak, di mana nilai p $(0,200)$ diperoleh. Kesimpulan: Status gizi terbanyak yang ditemukan dalam penelitian ini adalah gizi baik dan tidak ada hubungan antara tingkat pendidikan orang tua dan status gizi anak-anak di keluarga asuh Fakultas Kedokteran Universitas Muhammadiyah Sumatera Utara.

Kata kunci: Status gizi, Tinggi, Antropometri
\end{abstract}

\begin{abstract}
Background: The problem of nutrition is no longer merely a health problem, but also the problem of education, poverty, and employment opportunities. There are 4 sub-forms of nutritional deficiencies: wasting, stunting, underweight, and deficiencies of vitamins and minerals. Many studies have proven that one of the basic causes of wasting and stunting is a condition of low (poor) education and family economics. This study aims to determine the relationship of the level of education of parents to the nutritional status of primary school-age children in the fostered families of the Medical Faculty of Universitas Muhammadiyah Sumatera Utara. Method: The design of this study was descriptive analytic with a crosssectional study type. The population of this study amounted to 25 mothers with 43 total childrens who were registered as members of the Fostered Family of Medical Faculty Universitas Muhammadiyah Sumatera Utara. The sampling technique uses the total sampling method. Results: There was no relationship between parental education and the nutritional status of children, where $p$ values (0.200) were obtained. Conclusion: The most nutritional status found in this study is well nourished and there is no relationship between the level of education of parents and the nutritional status of children in the fostered families of the Medical Faculty of Universitas Muhammadiyah Sumatera Utara.
\end{abstract}

Keywords: Nutritional status, Height, Anthropometry. 


\section{PENDAHULUAN}

Masalah gizi pada hakikatnya adalah masalah yang kompleks. Pada kasus tertentu, seperti dalam keadaan krisis, masalah gizi sering muncul akibat masalah pangan di tingkat rumah tangga. Dalam hal ini, masalah gizi tidak lagi semata-mata masalah kesehatan, tetapi juga masalah kemiskinan, pendidikan, dan masalah kesempatan kerja. ${ }^{1}$ Gizi yang baik akan menghasilkan SDM yang sehat, cerdas, berkualitas, dan memiliki fisik yang tangguh serta produktif. ${ }^{4}$ Salah satu faktor yang mempengaruhi pertumbuhan ekonomi adalah sumber daya manusia (pendidikan), dimana dengan semakin tinggi tingkat pendidikan akan memberikan produktivitas sumber daya manusia yang tinggi. ${ }^{5}$ Berdasarkan Human Development Index (HDI), Indonesia berada pada peringkat 113 dari 187 negara. Faktor-faktor penentu HDI yang dikembangkan oleh United Nations Development Program (UNDP) adalah pendidikan, kesehatan, dan ekonomi. Ketiga faktor tersebut sangat berkaitan dengan status gizi masyarakat. ${ }^{2}$

Status gizi merupakan ekspresi dari keadaan keseimbangan dalam bentuk variabel tertentu, atau perwujudan dari nutrisi dalam bentuk variable tertentu. Penilaian status gizi secara langsung dapat dibagi menjadi empat penilaian yaitu antropometri, klinis, biokimia, biofisika (melihat perubahan struktur jaringan). ${ }^{1}$ Ada 4 sub-bentuk defisiensi gizi: wasting, stunting, underweight, dan defisiensi vitamin dan mineral. Kekurangan gizi membuat anak-anak khususnya jauh lebih rentan terhadap penyakit dan kematian. ${ }^{6}$
Menurut World Health Organization (WHO), 52 juta anak di bawah usia 5 tahun mengalami wasting, 17 juta mengalami wasting yang berat dan 155 juta mengalami stunting, sementara 41 juta kelebihan berat badan atau obesitas. Sekitar 45\% kematian di antara anak-anak di bawah usia 5 tahun terkait dengan kekurangan gizi. Ini kebanyakan terjadi di negara-negara berpenghasilan rendah dan menengah. Pada saat yang sama, di negara-negara yang sama ini, tingkat kelebihan berat badan dan obesitas anak meningkat. ${ }^{6}$

Sedangkan pada hasil Riskesdas tahun 2016, sekitar $61,1 \%$ anak memiliki tinggi badan dan berat badan ideal (TB/U normal dan $\mathrm{BB} / \mathrm{TB}$ normal) sedangkan $38,9 \%$ masih mengalami masalah gizi terutama dengan tinggi badan dan berat badan (pendek - normal). Sedangkan persentase wasting/kurus/sangat kurus untuk anak usia sekolah dan remaja berdasarkan indeks masa tubuh di Sumatera Utara adalah sekitar 2,7\% untuk anak usia 5-12 tahun, 2,4\% untuk usia 13-15 tahun, dan 0,6\% usia 16-18 tahun. Di Kota Medan anak yang mengalami underweight/gizi kurang sekitar $14,5 \%$, stunting/pendek 22,9\%, wasting/kurus $16,9 \%$, dan gemuk $16,9 \% .^{7}$ Berdasarkan persentase hasil Riskesdas diatas, Kota Medan termasuk dalam kategori akut-kronis ${ }^{7}$ dan jumlah kejadian terbesar terjadi pada anak usia sekolah dasar ( $\pm 7-12$ tahun), hal ini terbukti pada hasil riskesdas tersebut.

Banyak penelitian yang
membuktikan bahwa salah satu
penyebab dasar dari wasting dan


stunting adalah kondisi tingkat pendidikan dan ekonomi keluarga yang rendah (miskin). Kemiskinan mengakibatkan keluarga tersebut mengalami keterbatasan dalam memenuhi kebutuhan gizi keluarga dari segi kualitas maupun kuantitas. Menurut penelitian Delmi Sulastri di Kecamatan Lubuk Kilangan Kota Padang, tingkat pendidikan dan tingkat ekonomi merupakan faktor diterminan terhadap kejadian stunting di Kecamatan tersebut. ${ }^{8}$ Berdasarkan hasil penelitian Lutviana dan Budiono, menunjukkan bahwa tingkat pendidikan ibu yang lebih tinggi cenderung mempunyai anak dengan status gizi yang lebih baik. ${ }^{9}$ Begitu juga dengan hasil penelitian Hadivian dan Sylvia, ada pengaruh pengetahuan, sikap praktek ibu tentang gizi dan pendapatan keluarga terhadap tingkat kecukupan energi dan protein anak. ${ }^{10}$ Namun hasil-hasil penelitian diatas tidak sejalan dengan hasil penelitian Fardhiasih dan Taurina, yaitu tidak ada hubungan antara tingkat pendidikan ibu dan pendapatan dengan status gizi anak prasekolah dan sekolah dasar. ${ }^{11}$

Berdasarkan data Riskesdas diatas Fakultas Kedokteran UMSU memiliki inisiatif untuk melakukan kerjasama dengan Dinas Kesehatan Kota Medan dan Camat Medan Denai untuk membentuk Program Keluarga Binaan Kesehatan (PKBK). Metode yang digunakan pada PKBK merupakan metode partisipatif, terstruktur, dan sistematis yang tidak hanya menguntungkan mahasiswa FK UMSU tetapi juga menguntungkan masyarakat. ${ }^{12}$ Laporan hasil PKBK berupa family folder dimana terdapat informasi mengenai tingkat pendidikan orang tua dan antropometri anak.

Di wilayah PKBK FK UMSU belum ada penelitian yang berhubungan dengan pendidikan orang tua dan gizi anak, maka peneliti tertarik untuk melakukan penelitian tentang adanya hubungan antara tingkat pendidikan orang tua dengan status gizi anak pada masyarakat di daerah keluarga binaan Fakultas Kedokteran Universitas Muhammadiyah Sumatera Utara.

\section{METODE PENELITIAN}

Metode penelitian pada penelitian ini adalah penelitian deskriptif analitik dengan jenis studi cross-sectional. Metode ini merupakan metode penelitian yang hanya dilakukan pengamatan sewaktu tanpa diperlukannya followup.

Penelitian dilakukan di dua Kecamatan yakni Kecamatan Medan Denai dan Medan Johor, di Medan Denai dilaksanakan di Kelurahan Tegal Sari Mandala II dan Tegal Sari Mandala III, sedangkan di Medan Johor dilaksanakan di Kelurahan Pangkalan Mashur dan Titi Kuning. Penelitian ini dilakukan dalam waktu 3 bulan (Oktober 2018 - Desember 2018).

Populasi pada penelitian ini berjumlah 25 orang ibu dengan total 43 anak yang terdaftar sebagai anggota Keluarga Binaan Fakultas Kedokteran Muhammadiyah dengan kriteria :

Kriteria inklusi :

1. Keluarga yang terdaftar sebagai keluarga binaan FK UMSU. 
2. Keluarga binaan yang memiliki anak usia 7-12 tahun.

3. Terdapat hasil pengukuran antropometri pada pertemuan pertama sebagai keluarga binaan yang tercatat di family folder PKBK.

4. Bersedia sebagai responden.

5. Ibu rumah tangga di keluarga binaan

Kriteria eksklusi :

1. Pendidikan informal ibu.

2. Jenis kelamin anak tidak jelas (ambiguous genetalia).

3. Pendidikan formal dan informal ayah.

Pada penelitian ini data yang dikumpulkan terdiri dari data sekunder yang berupa tingkat pendidikan dan data antropometri anak diperoleh dari family folder keluarga PKBK yang bersangkutan.

Instrumen penelitian ini adalah family folder untuk mendapatkan tingkat pendidikan orang tua dan hasil pengukuran antropometri, kurva CDC 2000.

Pengolahan data penelitian ini dengan Editing, Coding, Entri, Cleaning Data, dan Saving.

Analisis data yang digunakan pada penelitian ini adalah analisis bivariat. Selanjutnya dilakukan uji statistik menggunakan uji spearman, uji spearman digunakan untuk menguji tabel yang lebih dari $2 \times 2$. Apa bila nilai $\mathrm{p}<0,05$ maka hipotesis (Ho) ditolak dan perlu dilakukan penilain kekuatan korelasi (r), sedangkan jika nilai $\mathrm{p}>0,05$ maka hipotesis (Ho) diterima.

\section{HASIL PENELITIAN}

Penelitian ini dilakukan di dua Kecamatan yakni Kecamatan Medan Denai dan Medan Johor, di Medan
Denai dilaksanakan di Kelurahan Tegal Sari Mandala II dan Tegal Sari Mandala III, sedangkan di Medan Johor dilaksanakan di Kelurahan Pangkalan Mashur dan Titi Kuning.

Tabel 4.1. Distribusi frekuensi anak berdasarkan umur

\begin{tabular}{lll}
\hline & $\mathbf{n}$ & $\mathbf{\%}$ \\
\hline $\begin{array}{l}\text { Usia } \\
\text { (Tahun) }\end{array}$ & & \\
7 & 9 & $20,9 \%$ \\
8 & 8 & $18,6 \%$ \\
9 & 5 & $11,6 \%$ \\
10 & 5 & $11,6 \%$ \\
11 & 3 & $7 \%$ \\
12 & 13 & $30,2 \%$ \\
\hline Total & 43 & $100 \%$ \\
\hline
\end{tabular}

Berdasarkan tabel 4.1 didapati hasil bahwa umur anak yang tertinggi berusia 12 tahun, yaitu sebanyak 13 orang $(30.2 \%)$ disusul oleh usia 7 tahun sebanyak 9 orang (20.9\%), lalu usia 8 tahun sebanyak 8 orang (18.6\%) dan usia 9 dan 10 tahun yang masing-masing berjumlah 5 orang (11.6\%). Jumlah paling sedikit ditemui pada kelompok usia 11 tahun yaitu sejumlah 3 orang $(7 \%)$.

Tabel 4.2. Distribusi frekuensi anak berdasarkan jenis kelamin

\begin{tabular}{lll}
\hline $\begin{array}{l}\text { Jenis } \\
\text { Kelamin }\end{array}$ & $\mathbf{n}$ & $\mathbf{\%}$ \\
\hline Laki-laki & 26 & $25 \%$ \\
Perempuan & 34 & $32,7 \%$ \\
\hline Total & $\mathbf{1 0 4}$ & $\mathbf{1 0 0 \%}$ \\
\hline
\end{tabular}

Berdasarkan tabel 4.2 didapatkan hasil bahwa anak dengan jenis kelamin laki-laki adalah yang terbanyak dengan 25 orang $(58.1 \%)$ lalu anak perempuan sebanyak 18 orang $(41.9 \%)$. 
Tabel 4.3. Distribusi frekuensi tingkat pendidikan orangtua

\begin{tabular}{lll}
\hline $\begin{array}{l}\text { Tingkat } \\
\text { Pendidikan }\end{array}$ & n & \% \\
\hline SD & 5 & 11,6 \\
SMP & 11 & $25,6 \%$ \\
SMA & 25 & $58,1 \%$ \\
Perguruan & 2 & $4,7 \%$ \\
Tinggi & & $\mathbf{1 0 0 \%}$ \\
\hline Total & $\mathbf{4 3}$ & \\
\hline
\end{tabular}

Pada tabel 4.3 disajikan bahwa tingkat pendidikan ibu yang paling banyak pada responden adalah SMA, sebanyak 25 orang (58.1\%). Sedangkan pendidikan SMP berjumlah 11 orang $(25.6 \%)$. Tingkat pendidikan ibu yang SD dan Perguruan Tinggi masing-masing berjumlah 5 orang dan 2 orang (11.6\% dan 4.7\%).

Tabel 4.4. Distribusi frekuensi anak berdasarkan status gizi

\begin{tabular}{lll}
\hline Status Gizi & n & \% \\
\hline Gizi Baik & 21 & $48,8 \%$ \\
Gizi Kurang & 20 & $46,5 \%$ \\
Gizi Buruk & 2 & $4,7 \%$ \\
\hline Total & $\mathbf{4 3}$ & $\mathbf{1 0 0 \%}$ \\
\hline
\end{tabular}

Berdasarkan tabel 4.4, pada anak ditemukan paling banyak dalam kategori gizi baik yaitu sebanyak 21 orang (48.8\%) lalu gizi kurang sebanyak 20 orang $(46.5 \%)$ dan yang paling sedikit adalah gizi buruk sebanyak 2 orang (4.7\%).

Dalam analisis data peneliti menggunakan uji statistik Spearman dimana peneliti ingin mengetahui ada tidaknya hubungan tingkat pendidikan orang tua terhadap status gizi anak usia sekolah dasar pada keluarga daerah binaan FK UMSU angkatan 2015 s/d 2017. Tingkat kemaknaan yang dipakai adalah $\alpha=$ 0,05 .

Uji ini digunakan karena penelitian ini merupakan penelitian korelatif dengan variabel ordinalordinal. Variabel akan dikatakan berhubugan secara signifikan apabila nilai $\mathrm{p}<0,05$ dan dikatakan tidak berhubungan apabila nilai $p>0,05$. Hasil analisis dapat dijelaskan pada table dibawah ini:

Tabel 4.5. Hubungan tingkat pendidikan dengan status gizi pada responden

\begin{tabular}{|c|c|c|c|c|c|c|}
\hline \multirow[b]{2}{*}{ Tingkat Pendidikan } & & \multicolumn{3}{|c|}{ Status Gizi } & \multirow[b]{2}{*}{ Total } & \multirow[t]{2}{*}{$\begin{array}{l}\text { Nilai p } \\
\end{array}$} \\
\hline & & Gizi Baik & Gizi Kurang & $\begin{array}{c}\text { Gizi } \\
\text { Buruk }\end{array}$ & & \\
\hline SD & $\mathrm{N}$ & $\begin{array}{c}1 \\
200 \%\end{array}$ & $\begin{array}{c}4 \\
80 . \%\end{array}$ & 0 & 5 & \multirow{5}{*}{0.200} \\
\hline SMP & $\begin{array}{l}\mathrm{N} \\
\%\end{array}$ & $\begin{array}{c}5 \\
45.5 \%\end{array}$ & $\begin{array}{c}6 \\
54.5 \%\end{array}$ & $\begin{array}{c}0 \\
0.0 \%\end{array}$ & $\begin{array}{c}11 \\
100.0 \%\end{array}$ & \\
\hline SMA & $\begin{array}{l}\mathbf{N} \\
\% \\
\%\end{array}$ & $\begin{array}{c}13 \\
52.0 \%\end{array}$ & $\begin{array}{c}10 \\
40.0 \%\end{array}$ & $\begin{array}{c}2 \\
8.0 \%\end{array}$ & $\begin{array}{c}25 \\
100.0 \%\end{array}$ & \\
\hline Perguruan Tinggi & $\begin{array}{l}\mathbf{N} \\
\%\end{array}$ & $\begin{array}{c}2 \\
100.0 \%\end{array}$ & $\begin{array}{c}0 \\
0.0 \%\end{array}$ & $\begin{array}{c}0 \\
0.0 \%\end{array}$ & $\begin{array}{c}2 \\
100.0 \%\end{array}$ & \\
\hline Total & $\begin{array}{l}\mathbf{N} \\
\%\end{array}$ & $\begin{array}{c}21 \\
48.8 \%\end{array}$ & $\begin{array}{c}20 \\
46.5 \%\end{array}$ & $\begin{array}{c}2 \\
4.7 \%\end{array}$ & $\begin{array}{c}43 \\
100.0 \%\end{array}$ & \\
\hline
\end{tabular}

Berdasarkan tabel 4.5, anak dengan orangtua berlatar belakang pendidikan SMA, terdapat 13 orang diantaranya dalam gizi baik $(52 \%)$, sedangkan gizi kurang dan gizi buruk ditemui masing-masing berjumlah 10 orang $(40 \%)$ dan 2 orang (8\%). Untuk pendidikan SMP, 5 orang ditemukan dengan status gizi baik (45.5\%) sedangkan 6 orang dalam status gizi kurang $(54.5 \%)$ dan tidak ditemukan dalam status gizi buruk.

Sedangkan pendidikan SD, ditemukan sebanyak 1 orang dengan status gizi baik $(20 \%), 4$ orang dengan status gizi kurang (80\%) dan tidak ditemukan status gizi buruk. Yang paling sedikit adalah orangtua anak dengan latar belakang perguruan tinggi, sebanyak 2 orang masuk dalam kategori gizi baik $(100 \%)$ sedangkan tidak ditemukan dalam kategori gizi kurang ataupun buruk $(0 \%)$.

\section{PEMBAHASAN}


Berdasarkan tabel 4.4, pada anak ditemukan paling banyak dalam kategori gizi baik yaitu sebanyak $48.8 \%$ lalu gizi kurang sebanyak $46.5 \%$ dan yang paling sedikit adalah gizi buruk sebanyak $4.7 \%$. Hal ini sejalan dengan penelitan sebelumnya terkait Distribusi Responden Menurut Status Gizi dan Kelompok Umur di Desa Ngemplak, yang menunjukkan bahwa sebagian besar sampel di daerah tersebut yang berstatus gizi baik yaitu sebesar $85.14 \%$, sampel dengan status gizi kurang sebesar $10.81 \%$ dan sampel dengan status gizi buruk 1,35\%. Pada penelitian tersebut tingkat pendidikan ibu tidak berpengaruh terhadap status gizi anak tetapi ditemukannya pengaruh tingkat pengetahuan terhadap status gizi anak dengan nilai $\mathrm{p}=0,009$, dimana pada penelitian tersebut ditemukan tingkat pendidikan tinggi belum tentu memiliki tingkat pengetahuan yang tinggi. ${ }^{13}$

Berdasarkan tabel 4.5, ditemukan nilai $\mathrm{p}=0.200(\mathrm{p}>\alpha)$ yang bermakna tidak ada hubungan antara tingkat pendidikan dengan status gizi pada anak. Gizi buruk yang didapatkan mungkin dipengaruhi oleh tingkat pengetahuan orang tua yang kurang dan pengaruh dari faktor lain seperti sosio ekonomi keluarga dan mungkin disebabkan oleh faktor langsung yaitu asupan makanan ataupun penyakit infeksi yang mungkin dialami oleh si anak dimana pada beberapa anak dijumpai riwayat penyakit terdahulu yang tertera pada family folder.

Hal ini selaras dengan penelitian sebelumnya yang menyatakan dalam uji hubungan didapatkan $\mathrm{p}=0,632$, bermakna $\mathrm{p}>\alpha$ artinya tidak ada hubungan antara tingkat pendidikan responden dengan status gizi di daerah tersebut. Dalam penelitian ini, ibu yang memiliki tingkat pendidikan rendah tidak selalu memiliki anak dengan masalah gizi yang lebih banyak daripada ibu dengan tingkat pendidikan lebih tinggi. Hal ini dikarenakan tingkat pendidikan ibu tidak merupakan penyebab dasar dari masalah kurang gizi, dan masih banyak faktor- faktor lain yang dapat memengaruhi terjadinya masalah kurang gizi, khususnya pada keluarga miskin. ${ }^{14}$

Hal ini juga sejalan dengan penelitian lain tentang Hubungan Antar Tingkat Pendidikan Orang Tua dengan Status Gizi Siswa SDN Campurejo dimana didapatkan nilai $\mathrm{p}$ $=0,060$ yang menunjukkan bahwa tidak adanya hubungan. Pada penelitian tersebut orang tua dengan tingkat pendidikan rendah dan tingkat pendidikan tinggi tidak memiliki anak dengan status gizi kurang, maka dari hasil tersebut semangkin menunjukkan bahwa tidak berhubungan antara tingkat pendidikan orang tua dengan status gizi anak. ${ }^{15}$

Tetapi hal ini tidak sejalan dengan penelitian lain yang meneliti Hubungan Antara Tingkat Pendidikan Orangtua dengan Status Gizi Anak, dimana hasil penelitian tersebut menunjukkan adanya hubungan dengan nilai korelasinya sebesar 0,590, yang bermakna hasil penelitian menunjukan bahwa tingkat pendidikan orangtua berhubungan kuat dengan status gizi anak. Hal ini mungkin dipengaruhi oleh tingkat penghasilan orang tua pada penelitian tersebut dimana rata-rata penghasilan orang tua dengan tingkat 
pendidikan tinggi adalah $>\mathrm{Rp}$ 1.500.000,- dan tidak dijumpai penghasilan orang tua $<\mathrm{Rp}$ 800.000,-. Peneliti tersebut berpendapat orangtua yang memiliki pendapatan yang memadai akan menunjang status gizi anak, karena orangtua dapat menyediakan semua kebutuhan anak baik primer maupun skunder. ${ }^{16}$

\section{KESIMPULAN}

Berdasarkan hasil penelitian tentang Hubungan antara Pendidikan Orang Tua dengan Status Gizi Anak pada Keluarga Binaan FK UMSU, diperoleh kesimpulan sebagai berikut:

1. Tidak ada hubungan antara tingkat pendidikan ibu dengan status gizi anak, dimana diperoleh nilai $\mathrm{p}$ $(0,200)$.

2. Status gizi terbanyak yang ditemukan pada penelitian ini adalah gizi baik.

3. Tingkat pendidikan ibu pada Keluarga Binaan FK UMSU terbanyak adalah SMA.

Berhubung pada penelitian ini masih ditemukan anak dengan status gizi kurang dan gizi buruk, maka saran yang dapat peneliti berikan adalah:

1. Diharapakan kepada pemerintah untuk melakukan edukasi tentang gizi anak kepada masyarakat pada penelitian ini.

2. Kepada orang tua dengan anak yang memiliki status gizi baik diharapkan dapat mempertahankan status gizi anak, sedangkan kepada orang tua dengan anak yang memiliki status gizi kurang dan buruk untuk meningkatkan dan memperhatikan asupan gizi anak.

\section{REFERENSI}

1. I Dewa Nyoman Supariasa, Bachyar Bakri IF. Penilaian Status Gizi. Vol 40; 2002. doi:10.1016/S09694765(04)00066-9

2. Elisa Pahlevi A. Determinan Status Gizi Pada Siswa Sekolah Dasar. J Kesehat Masy. 2012;7(2):122-126.

3. Organisation WH. WHO | Malnutrition. WHO. 2017. http://www.who.int/mediacen tre/factsheets/malnutrition/en/ . Accessed April 21, 2018.

4. UNDP. Human Development Report 2016: Indonesia. United Nations Dev Program. 2016:1-8. http://hdr.undp.org/.

5. Kemenkes RI. Hasil Pemantauan Status Gizi (PSG) 2016. Biro Komun dan Pelayanan Masy. 2017:140. http://sehatnegeriku.kemkes.g o.id/baca/rilismedia/20170203/0319612/ini lah-hasil-pemantauan-statusgizi-psg-2016/.

6. Todaro MP. Pembangunan Ekonomi Di Dunia Ketiga. In: Economic Development. ; 2008. doi:2003

7. Organisation WH. WHO Malnutrition. WHO. 2017. http://www.who.int/mediacen tre/factsheets/malnutrition/en/ . Accessed April 21, 2018.

8. Anak P, Sekolah U, Kecamatan DI, Kilangan L, Padang K. Faktor Determinan Kejadian Stunting. :39-50.

9. Lutviana E, Budiono I. 
Prevalensi dan determinan kejadian gizi kurang pada balita. $J$ Kesehat Masy. 2010;5(2):138-144.

http://journal.unnes.ac.id/nju/ index.php/kemas/article/view $/ 1872$.

10. Hardiviani SL. Pengaruh Karakteristik Ibu dan Pendapatan Keluarga Terhadap Tingkat Kecukupan Energi dan Protein Serta Status Gizi Anak Balita di Desa Suwawal Barat, Kecamatan Mlonggo, Kabupaten Jepara. 2013.

11. Astuti FD, Sulistyowati TF. Hubungan Tingkat Pendidikan Ibu dan Tingkat Pendapatan Keluarga dengan Status Gizi Anak Prasekolah dan Sekolah Dasar Di Kecamatan Godean. $J$ Kesehat Masy (Journal Public Heal. 2013;7(1):1520.

http://journal.uad.ac.id/index. $\mathrm{php} /$ KesMas/article/view/123 7 .

12. Boy E, Ilmu D, Masyarakat K, Kedokteran F, Muhammadiyah U, Utara S. EFEKTIFITAS

$\begin{array}{lr}\text { PELATIHAN } & \text { KADER } \\ \text { KESEHATAN } & \text { DALAM } \\ \text { PENANGANAN } & \\ \text { TUBERKULOSIS } & \text { DI } \\ \text { WILAYAH } & \text { BINAAN. } \\ 2015 ; 4(2): 83-89 . & \end{array}$

13. Wahyuni S. 2009. Hubungan Tingkat Pengetahuan Ibu Tentang Gizi Dengan Status Gizi Anak Balita Di Desa Ngemplak Kecamatan Karangpandan

Kabupaten Karanganyar.
Universitas Sebelas Maret Surakarta. Hal 48.

14. Ni'mah C, Muniroh L. 2015. Hubungan Tingkat Pendidikan, Tingkat Pengetahuan Dan Pola Asuh Ibu Dengan Wasting Dan Stunting Pada Balita. Media Gizi Indonesia, Vol. 10, No. 1 Januari-Juni 2015: hlm. 8490

15. Saputro D., Nurhayati F. Hubungan Antara Tingkat Pendidikan Orang Tua dengan Status Gizi Siswa SDN Campurejo I Bojonegoro. $J$ Pendidik Olahraga dan Kesehat. 2014;2(3):627-630.

16. Febrianto, D. 2012. Hubungan Tingkat Penghasilan, Tingkat Pendidikan dan Tingkat Pengetahuan Orangtua Tentang Makanan Bergizi Dengan Status Gizi Siswa Sekolah Islam Zahrotul Ulum Karangampel Indramayu. Fakultas Ilmu Keolahragaan, Universitas Negeri Yogyakarta. Hal 55 